\title{
INTERNAL CONTROL SYSTEM AS CONTINUOUS BASIS OF EFFICIENT AND STABLE COMPANY DEVELOPMENT
}

\author{
LudMILA VEROVSKA ${ }^{1}$
}

The Baltic International Academy (Latvia)

\begin{abstract}
In condition of global financial crisis companies and investors pay greater and greater attention to the reliability of financial records. An efficient system of internal control (ICS) contributes significantly to this effect. The aim of the research is to consolidate the international experience in the sphere of the development and regulation of the system of internal control, to assess the feasibility of its application to various Latvian enterprises, and to propose a conception and a model of realisation of ICS in medium and small companies. According to the author, there are two main obstacles to the application of the studied theories relevant to the field of internal control in Latvia. The first one is the insufficiency of legislative framework, intended only for listed companies, and the second one is a start-up phase of business development, when the owner and top management are often combined in one and the same person and, therefore, they may believe that all is under their control and there is no need to create a special system of control. The theoretical and methodological foundation of the research was derived from the study of a wide range of activities in the field of corporate management and internal control as well as provisions of regulatory and legislative acts defining the scope of requirements to ICS. In order to achieve the set aim, several objectives were realised: the regulation of ICS in the area of corporate legislation of the USA and the EU was analysed; the conceptual principles and existing models of internal control were summarised; the concept of development of the ICS for medium and small enterprises was formulated, and the necessity to introduce recommendations to the currently effective legislation of Latvia was substantiated.

KEYWORDS: Internal control system (ICS), model COSO, regulation of EU corporate legislation, operation of ICS in small and medium companies, non-public sector companies.
\end{abstract}

\section{JEL CODES: M42}

\section{Introduction}

The internal control is an integral part of efficient company management. Its principal aim is to create the competitive advantage of a company, to increase its financial stability, and instill confidence in investors to the credibility of presented records, which issues have become especially urgent in the context of economic recession. Investors want to be sure that the enterprise wherein they invested their money operates on universal and comprehensible principles, presented reports are reliable, and their interests are protected.

The choice of a form of the internal control depends on the complexity of the company's structure, its legal form, the scale of activity, features of the industrial segment in which a company operates, reasonable expediency, and sensible managerial attitude to the issue of control. The introduction of ICS is a sophisticated creative process, where the formal approach is impossible even when the degree of methodological elaboration is high. Every enterprise is unique and ICS will be characteristic of the company where it is applied.

The object of research is ICS, its implementation in a company and its legal regulation.

I Ludmila Verovska - the Baltic International Academy, Financial Management Faculty, as. prof., Dr. oec. Scientific interest: Financial Management, Audit.

E-mail: mila.v@inbox.lv

Tel.: +371261006 46 . 
The purpose of the article is to develop recommendations based of the study of ICS conceptual principles for the creation of ICS in enterprises and for its evaluation by independent auditors.

The following research methods have been used in the paper: the analysis of scientific literature, comparative and statistical analyses, and systematization of existing views on the problem.

In the conditions of unstable economic growth and dynamic change of the business environment more attention is being attracted to creation of an efficient internal control system (ICS) in companies. ICS is not a novel phenomenon, many managers and owners of companies have used the internal control informally and unconsciously before, focusing on the expenditure of funds and preservation of material resources. When business activity becomes more complex, the risks increase, and the managerial process requires more qualified decisions. In this case an informal, weakly organized approach to the system of control may negate all the efforts of management. This is the reason why the topic of internal control has become actively studied in both methodological and organisational aspects and in the aspect of practical application.

\section{Model COSO}

The most authoritative study in the field of internal control is considered to be a methodology developed by the Committee of Sponsoring Organizations of the Treadwey Commission (COSO) founded in the USA in 1985 (Committee of Sponsoring Organizations of the Treadway Committee. COSO, 1992). The main task of the Committee was to give recommendations for corporate' management on key aspects of business organisation, business ethics, financial reporting, internal control, risk management and fraud prevention.

The development of COSO model went in several stages.

The first stage is associated with the report "The conceptual principles of internal control" published in 1992 which contained a general definition of internal control and described its model, with which the systems of internal control of different companies could be compared and improved. The internal control was seen as a process accomplished by the board of directors, management and other personnel of the company, and intended to provide sufficient certainty regarding the achievement of the company's objectives in the following three areas:

- the efficiency and productivity of operations;

- reliability of financial reports;

- observance of laws and regulations.

The proposed model included five components: the controlled environment, risk assessment, means of control, information and communication, and monitoring.

The second stage is associated with the initiation of the COSO project in 2001through which the conceptual foundations of risk management were developed. The results of the project were laid in the basis of Sarbanes-Oxley Act. According to this Act, public companies were required to create and maintain a system of internal control, and the management board of the company was required to provide information on the efficiency of this controlling system confirmed by an independent auditor. In 2004 the paper "Conceptual principles of the enterprise risk management" was published. The new COSO model continued considering the issues of internal control, but the emphasis was shifted to the concept of risk management.

"The conceptual principles of internal control" is still being used as the accepted standard in financial reporting.

The new model included five components of the previous model, and three new components: the internal environment, setting of objectives, identification of events, risk assessment and responding to risks, means of control, information and communication, and monitoring. The risk management model was aimed at achieving the goals of a company in the following four areas:

- strategic goals (the mission of a company);

- operational objectives (effective and efficient use of resources);

- objectives in the field of preparation of reports - the reliability of reports;

- objectives in the field of compliance with laws and legal regulations. 
The third stage was initiated by the report "The internal control over presentation of financial reports" published in 2006. The report provided a kind of guidance to small public companies. Its aim was to provide methodological assistance in how to apply the COSO model and introduce a system of efficient internal control in smaller companies.

\section{Regulation of EU corporate legislation}

There is a lack of uniform EU requirements to the organization of systems of internal control, but the discussion and the development of legislation on this issue has become increasingly active. The eighth EU Directive, adopted on 17 May 2006, is of particular importance to this effect (EU Directive 2006/46/EC). The Directive adopted three important provisions:

- the companies representing public interest, should appoint auditing committees, which will have a greater responsibility in risk management and the function of oversight of the systems of internal control and audit;

- such audit committees should be responsible for selecting an external auditor and for providing oversight of its independence;

- the report of the independent auditor should disclose significant deficiencies, if there are any, of the system of internal control over the processes of fpreparation of financial reports.

Directive required a high level of responsibility from the part of the board members for the content of reporting documents, improved the transparency of reporting on related party transactions and off-balance sheet items, and made the reporting documentation of internal corporate control mandatory for public companies.

How important is this for Latvia, where the number of public companies is small? There are 32 enterprises, including -7 active at Riga Stock Exchange (Birža NASDAQ OMX Riga). In 2011 the incomes of the largest of them were the following: stock-holding company AS "Olainfarm" - $€ 52.179 \mathrm{mln}$ (Financial statements AS “Olainfarm”), stock-holding company AS "Latvijas kuǵniecība” - €97.576 mln (Financial statements AS "Latvijas kuǵniecība"), stock-holding company AS "Grindeks" - €69.573 $\mathrm{mln}$ (Financial statements AS "Grindeks"). At the same time, there are a number of much larger companies functioning in Latvia, which though not public, are sistemgenerating major taxpaying enterprises, which activities affect the successful work of many other enterprises in Latvia. The example of such company is AS "Latvenergo" (Financial statements AS "Latvenergo"), which income totaled to $€ 963.84 \mathrm{mln}$ lats in 2010 . The recent corruption scandal associated with this company, confirms that the preparation of mandatory reporting documentation of internal corporate control should be extended to such enterprises, even though they are not public.

\section{The definition of internal control, its distinction from the internal audit}

The internal control is a process, which task is to provide reasonable guarantee that the specific goals are fulfilled in such areas as efficiency and necessity of work, responsibility of employees, the reliability of financial reports and their compliance with laws and regulations.

In contrast to the internal control, the internal audit verifies the effectiveness of the internal control. The responsibilities of the internal auditor do not include the establishment of internal control and its technical maintenance. The internal audit assesses the processes and procedures of the internal control within a certain period of time, i.e. temporarily, but the internal control is a continuous process. The internal control is a method that ensures the adequate level of protection against operational risks, including financial and liability risks. Implementation of the internal control in the company is first of all the duty of its director. Besides this, every employee is important in exercising control over operation of the company, usage of resources and performance of their official duties. The internal control is characterized by high ethical standards and values, which every employee should be aware of and share. 


\section{The efficient internal control and the boundaries of the internal control}

It is important to understand that no matter how well developed the measures of the internal control are, no matter how sufficient they may seem, there is no absolute guarantee that the internal control can detect and prevent fraud and help to achieve the goals of the company. The existence of the human factor suggests the possibility of error in judgment and processes. There is always a possibility that the internal control may be changed in the interests of particular individuals under the pressure of the company's management or conspiracy among employees.

The efficient internal control is based on balance. The structure of efficient internal control resides in the right balance between the cost of procedure and risks associated with it. If measures of internal control are excessive, this makes it expensive and that reduces the efficiency of a company and adversely affects the psychological climate of the team.

\section{The system of internal control}

The choice of the implementation form of the internal control depends on the complexity of the corporate structure, its legal form, the scale of activity, features of the industry segment, reasonable expediency, the attitude of management to the issue of control, and the requirements of owners. By developing an effective system of internal company control the administration board wishes to achieve several goals: to provide itself with reliable information, to convince investors in the reliability of financial reports; to ensure the effectiveness of the company's economic activity, to observe the compliance with the prescribed accounting policy and applicable laws and regulations. The introduction of ICS is a complex creative process, in which the formal approach is not possible, even when the degree of elaboration of a methodology is very advanced. Every enterprise is unique, and the ICS will be characteristic of the company, where it is applied. In its most general form the system of internal control can be represented as a flowchart shown in Figure 1 (prepared by the authors).

The environment of the company is created and used by the top management. This environment defines the corporate atmosphere, and all the employees are aware of this element of control. The management environment consists of the following factors:

- an intelligent corporate structure, based on the scale and nature of the company's activity;

- principles of integrity and ethical values set out clearly by the management and applied in practice,

- the personnel selection guided by the management commitment to hire only such people that observe ethical principles and have a required level of competence,

- a clear strategy of management and working style in relation to the preparation of financial documents, compliance with corporate policy and procedures, and delegation of responsibility.

The effective decision making is largely dependent on the quality of information available to decision makers. The company should receive timely information in electronic and in paper form, on both external and internal developments.

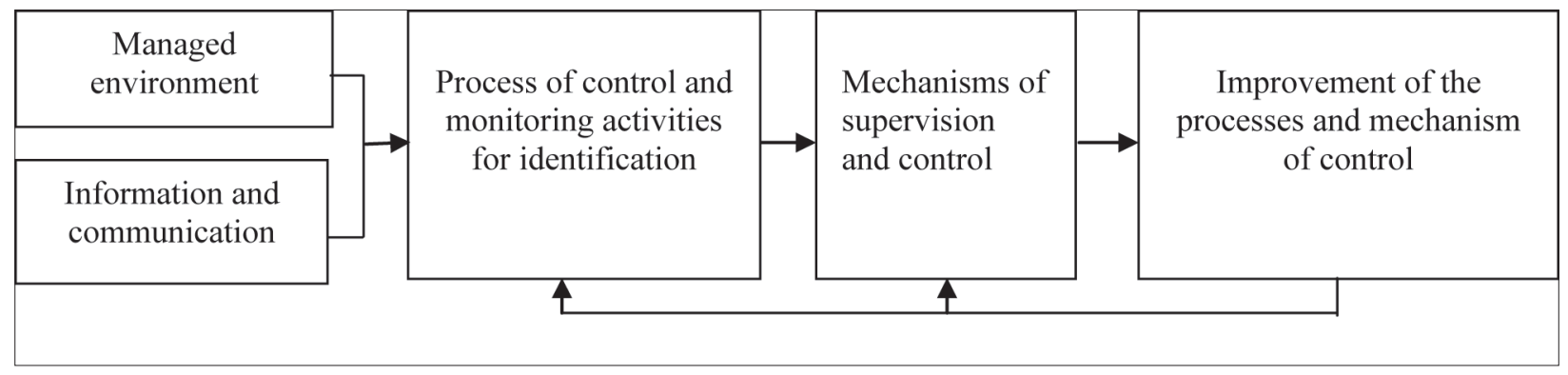

Figure 1. The system of internal control 


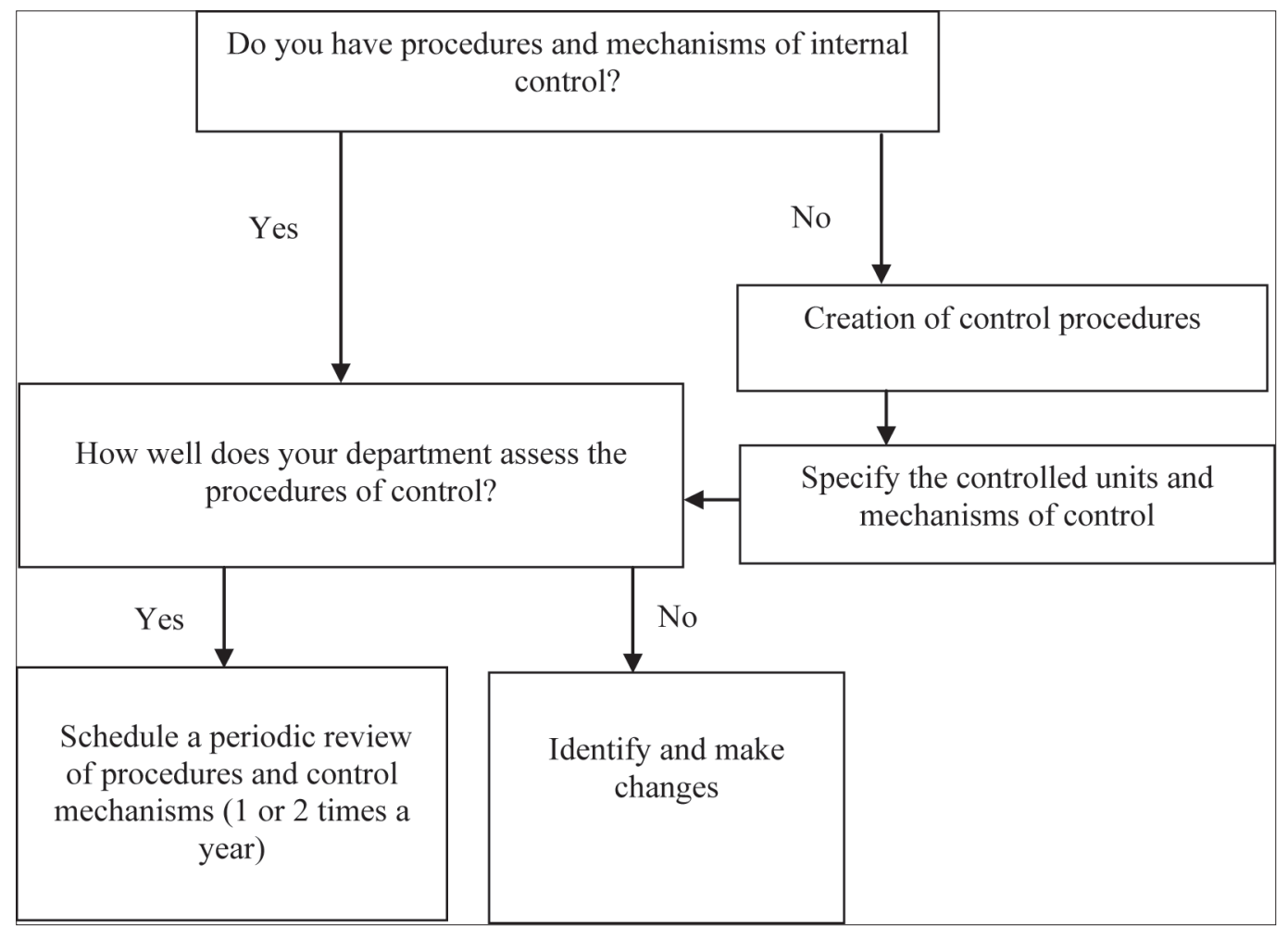

Figure 2. The block diagram representing the implementation of the internal control system

The communication systems of the company are its information channels and methods of transmission. In order to achieve maximum efficiency it is necessary to ensure a free flow of communication among all levels of personnel in the company as well as at the level of its departments and divisions. In the event that the company has a regional unit, it is necessary to ensure effective and regular communication between that and the central functional unit.

Controlling measures for achievement of the goals of the company consist of two elements:

- the policy of control;

- the procedures of control.

The policy of control can be represented in the form of instruction (formal method), which describes procedures and flowcharts, as well as in the oral or verbal form (informal method). Procedures for monitoring of specific activities can be performed manually or via computer. Examples of such activities are the comparison of the budget planned and factual performance, permission, approval, agreement of sums, access to computers, asset protection, etc. The division of responsibility for processing, registration and coordination of transactions, where more than one employee is involved, should be fixed by regulations.

The system of internal control (management environment, policies and procedures of control) is constantly changing. Therefore, in order to ensure the efficient control system, the management should periodically upgrade it. Monitoring can be used as a method of self-appraisal, or independent appraisal carried out by an internal or external auditor, or a combination of these methods. In the process of monitoring it is necessary to specify the strengths and weaknesses of the internal control. The authorized persons should be notified on the identified deficiencies and necessary changes should be made. Then a follow-up procedure should be entered as a next measure.

According to the results of monitoring the management board takes measures to reduce the risks of the company. These measures may be a change in the documentary statement of the distribution of duties, cor- 
rections in accounting or credit policy, etc. The system of the internal control of the company may be designed by an external expert, or by the company specialists (inside each department and division). But in order to fulfill the role of a monitoring agent, the internal audit should not be responsible for designing, creating, and maintaining of control. It can only make recommendations for improvement.

At the core of the implementation of ICS two approaches can be used: the integrated approach - when all aspects and all transactions of an enterprise are subject to control; and risk-based approach - when only those transactions are subject to control which risks are higher. The basis of choice is the principle of balance.

The implementation of the system of internal control can be represented in the block-diagram (Figure 2).

The system of internal control can be introduced in the operating activity gradually by divisions, or firstly by identifying operations of higher risk that require special attention.

\section{Conclusions}

ICS should not exist outside the major system of company management. It should be related to the mission, goals and objectives of the company and help to achieve the goals of administration. No matter how perfect a model of ICS could be, it will always tend to have certain limitations, and therefore cannot guarantee absolute protection, but it is able to reduce the risk of unreliable information and the possibility of fraud in the company.

Every company is unique and its goals, objectives and activities for their achievement are unique too. Every particular company should create its own model of the ICS integrated into its management structure.

ICS is not a static model; it changes and evolves together with the company. Despite the fact that the process of creating an ICS requires an investment, even the companies that do not have large resources are able to create their own system of internal control. The author's conception of the ICS means the sum total of a company structure, rules of its functioning and the exercise of control over the way how specific goals in such areas as the effectiveness and necessity of work, responsibilities of employees, the veracity of financial statements and their compliance with laws and regulations are accomplished. A possible variant of the ICS and its implementation in the operational functioning of a company are represented in block diagrams.

In the EU the requirements to the quality of ICS within companies have substantially increased over the past six years, but they relate mostly to the listed companies. The analysis proved that this is not sufficient. There is a need to extend these requirements to large public companies, which are not listed, but yet affect the development of all sectors of the economy of a state. The report of the management on the status of ICS in the company shall be confirmed in the public part of the conclusion made by an independent auditor.

\section{References}

Arens, A. A., Elder, R. I., Beasley, M. S. (2003). Auditing and assurance services an intergrated approach. 9th ed. Prentice Hall, 765 p.

Beasley, M. S., Bruce, C. B., Hancock, B. V. (2010). COSO’s 2010 Report on ERM. Current State of Enterprise Risk. Oversight and Market Perceptions of COSO's ERM Framwork. Website: www.erm.coso.org

Birža NASDAQ OMX. Riga. Website: http://www.nasdaqomxbaltic.com/market/?lang=lv

Committee of Sponsoring Organizations of the Treadway Commission (COSO). (1992). Internal Control - Integrated Framework. New York: AICPA, 1992.

Committee of Sponsoring Organizations of the Treadway Committee (COSO). (1992). Internal Control - Integrated Framework, Executive Summary. Website: www.coso.org

EU Directive 2006/46/EC. Website: http://www.standardsetter.de/drsc/docs/pressreleases/avendertung4 und7EURL140606engfinal.pdf

Financial statements $A S$ "Grindeks". Website: www.grindeks.lv

Financial statements AS "Latvenergo". Website: www.latvenergo.lv

Financial statements AS “Latvijas kugniecība”. Website: www.lk.lv

Financial statements AS “Olainfarm”. Website: www.olainfarm.lv 
Internal Control Working Party, Internal Control: Guidance for Directors on the Combined Code. (1999). London: The Institute of Chartered Accountants in England \& Wales.

The official Journal of the E.U. (2006). Website: http://guap.ru/news/55045

Аренс, А. А., Лоббек, Дж. К. (2003). Аудит (пер с англ.). Москва: Финансы и статистика, 558 с.

Гританс, Я. М. (2011). Система внутреннего контроля: как эффективно бороться с корпоративньм мошеничеством. Москва: Инфотропик Медиа, 304 с.

Гританс, Я. М. (2011). Формирование комплексной системы внутреннего контроля и защитты активов коммерческих организаций и холдингов. Москва: Тоска Testuite.

Дефлиз, Ф. Л., Дженик, Г. Р., О’Рейли, В. М., Хирш, М. Б. (1997). Аудит Монтгомери (пер. с англ.). Москва: Аудит, ЮНИТИ, 542 с.

Мюллер, Г., Гернан, Х., Минк, Г. (2003). Учет: международная перспектива (пер. с англ.). Москва: Финансы и статистика, $136 \mathrm{c}$.

Подход JSG к проектам по организации системы внутреннего контроля в компании. (2007). Website: www.isgr. $\mathrm{ru}$

Соколов, Б. Н. (2006). Внутренний контроль в коммерческой организации. Москва: Омега-Л, 250 с.

Соколов, Б. Н., Рукин, В. В. (2007). Системы внутреннего контроля (организация, методики, практика). Москва: Экономика, 448 с.

Харрингтон, Дж. Х. (1990). Управление качеством в американских корпорачиях (сокр.пер.с англ.). Москва: Экономика, 272 c.

\section{VIDINE KONTROLËS SISTEMA, KAIP NUOLATINÉS VEIKSMINGOS IR STABILIOS BENDROVES PLETROS PAGRINDAS}

LudMila VerovsKa

Tarptautinė Baltijos akademija (Latvija)

\section{Santrauka}

Kilus pasaulinei finansų krizei, bendrovès ir investuotojai vis labiau rūpinasi finansinių dokumentų patikimumu, ypač svarbi šiuo požiūriu veiksminga vidaus kontrolès sistema (IKS). Šio tyrimo tikslas - sutelkti tarptautinę vidinės kontrolès sistemos tobulinimo ir reguliavimo patirti, ỉvertinti jos pritaikymo Latvijos organizacijose galimybes bei pasiūlyti IKS igyvendinimo smulkiajame ir vidutiniame versle modeli. Autorès nuomone, siekiant vidinès kontrolès teorijas pritaikyti Latvijoje, kyla dvi pagrindinès problemos. Visų pirma - nepakankama teisinè bazè, antra - verslo steigimo fazè, kai bendrovès savininkas ir vadovas - vienas ir tas pats asmuo, dèl to gali susidaryti įspūdis, kad viskas yra kontroliuojama, todèl vidinès kontrolès sistemos nereikia. Teorinis ir metodinis tyrimo pagrindas - plataus spektro veiklų valdymo ir vidinès kontrolès analizè, teisès aktų, reguliuojančių IKS veiklą, nagrinèjimas. Siekiant išsikeltų tikslų, igyvendinti keli uždaviniai: išanalizuotas IKS teisinis reguliavimas JAV ir ES; apibendrinti konceptualūs esamų IKS modelių principai; pateikta IKS modelio smulkiam ir vidutiniam verslui koncepcija; atskleistas poreikis tobulinti esamą Latvijos teisinę bazę.

PAGRINDINIAI ŽODŽIAI: vidinès kontrolès sistema (IKS), COSO modelis, ES verslo teisè, IKS veikimas smulkiajame ir vidutiniame versle.

JEL KODAS: M42 